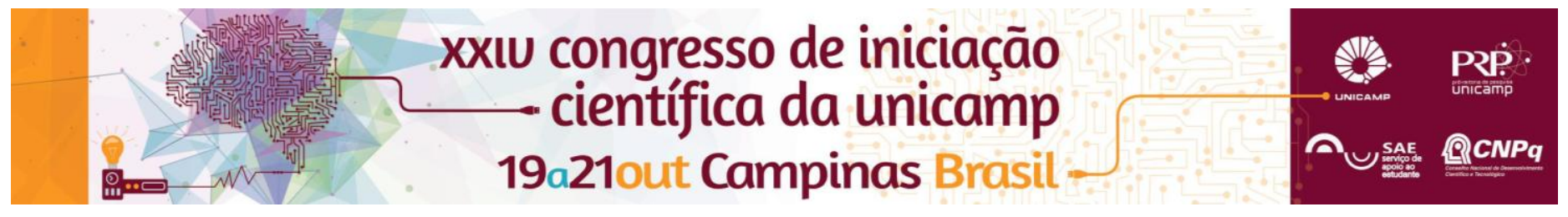

\title{
Aplicação de métodos de prototipagem rápida na construção de máquinas
}

\section{Giovanna Isabella Ventura*, Larissa Meneghini Silva*}

\section{Resumo}

As atividades desenvolvidas são voltadas a área de prototipagem rápida e servem para ampliar os conhecimentos sobre desenho técnico, automação de processos e montagem de equipamentos, através da criação de protótipos, desenvolvidos no programa Inkscape, da interpretação dos manuais de montagem utilizando como auxílio os materias de laboratórios e vídeos instrutivos que contribuiram para a realização do projeto proposto. Afim de otimizar processos na fabricação de figuras 3D com a montagem de alguns equipamentos como a extrusora, a fresadora e as impressoras 3D, foram executados sucessivos testes para certificar a eficiência de todos os procedimentos realizados e analisar se os objetivos foram alcançados.

Palavras-chave:

Prototipagem, otimização, modelagem tridimencional

\section{Introdução}

O projeto de iniciação científica visa instruir os alunos na montagem de três importantes máquinas para a realização da prototipagem rápida, que é um conjunto de tecnologias usadas para fabricar objetos físicos a partir de fontes de dados gerados por sistemas de projetos auxiliados por computador (CAD). Com intuito de desenvolver as habilidades necessárias para utilização, montagem e programação das máquinas extrusora, fresadora e impressora 3D, os professores orientadores se organizaram e distribuíram funções para construir o conhecimento necessário aos alunos para o início da montagem das máquinas, fornecendo os meios para compreensão do processo de prototipagem desde o estudo da eletrostática e eletrodinâmica até o trajeto da energia elétrica ao receptor eletrônico, arduíno, afim de que os alunos sintetizassem tais informações $e$ as utilizassem para a montagem das máquinas.

\section{Resultados e Discussão}

A montagem das máquinas serve para otimizar os processos de prototipagem rápida, cujo objetivo é formar objetos físicos (3D) rapidamente. Para comprovar e aprimorar a eficácia de cada mecanismo foi realizado testes e desenvolvidos cálculos para estabelecer as margens de erros e analisar os resultados.

Devido atrasos na entrega dos demais equipamentos (Fresdora e Impressoras 3D) não foi possível concluir a montagem e realizar os testes a tempo de inseri-los resultados alcançados.

Para calcular os desvios e avaliar a precisão de cada teste foi elaborada a seguinte tabela:

Tabela 1. Margens de erro do filamento- Extrusora.

\begin{tabular}{|l|l|l|l|}
\hline Analises & TESTE 1 & TESTE 2 & TESTE3 \\
\hline Erro Absoluto & 1.887 & 0.15 & 0.013 \\
\hline Erro real & 0.078 & 0.0857 & 0.007 \\
\hline Diâmetro $(\mathrm{mm})$ & 0.149 & 0.02 & 0.1653 \\
\hline
\end{tabular}

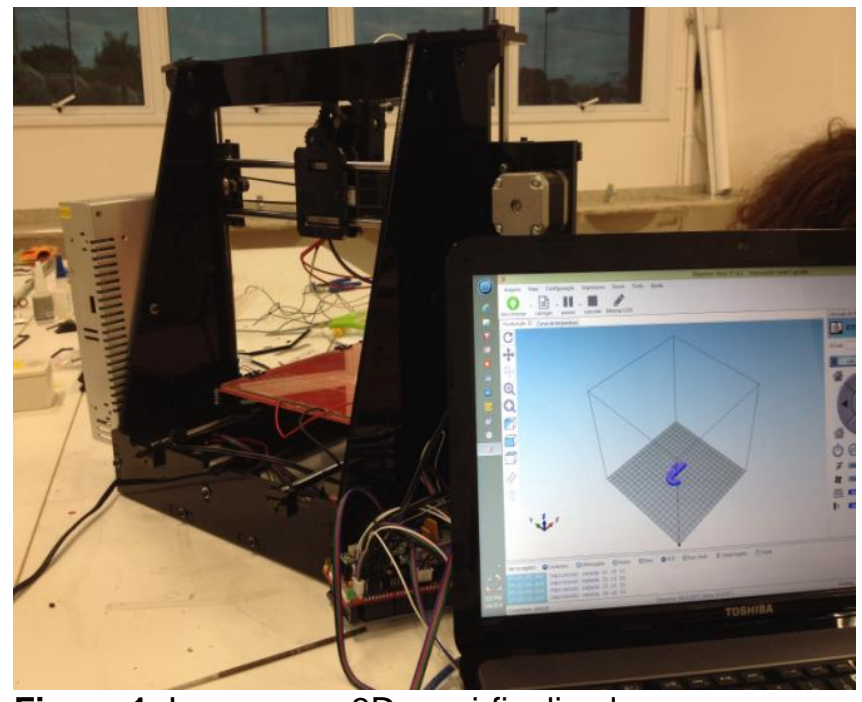

Figura 1. Impressora 3D semi-finalizada.

\section{Conclusões}

Conclui-se que os objetivos de montagem e introdução aos processos foram positivos, pois a partir da analises dos resultados obtidos na realização dos métodos, a equipe demonstrou-se apta a desenvolver as atividades propostas mediante ao prazo e os equipamentos concluídos até o presente momento executam com êxito sua função, entretanto, o projeto encontra-se em fase de finalização.

\section{Agradecimentos}

Agradecemos aos professores orientadores e aos alunos monitores, da instituição FCA Unicamp, pelo apoio e auxilio fornecido.

\footnotetext{
${ }^{1}$ Tutorial de Montagem Impressora 3D Graber i3 - GTMax3D. Disponível em file:///D:/Tutorial\%20Montagem\%20Graber\%20i3\%20GTMax3d\%20$\% 20$ Fase \%202.pdf. Acessado em: 23 de junho de 2016

2 PATSKO, Luís Fernando. Tutorial Controle de Motor de Passo. 2006

3 GORNI, Antonio Augusto. Introdução à prototipagem rápida e seus processos. Disponível em: http://www.gorni.eng.br/protrap.html. Acessado em: 17 de março de 2016
} 